\title{
KÍVÜL-BELÜL AKADÁLYMENTESEN
}

\author{
Angler Kinga \\ Pécsi Tudományegyetem Kultúratudományi, Pedagógusképző és Vidékfejlesztési Kar, Szekszárd \\ angler.kinga@pte.hu
}

DOI: 10.15170/TVT.2021.06.01.05

\begin{abstract}
Absztrakt
Az akadálymentes turizmus esélyt ad a fizikai, illetve az értelmi képességeiben akadályozott személyek számára, hogy - ép társaikhoz hasonlóan - turisztikai élményekhez juthassanak. A fogyatékossággal élő emberek igénye a turizmusban való részvételre egyre gyakoribbá válik napjainkban. A hazánkban rendelkezésre álló akadálymentes turisztikai szolgáltatások kínálata azonban jelentősen beszükíti lehetőségeiket. Idehaza kevés a kifejezetten akadálymentes turizmusra specializálódott vagy azt a tevékenységet támogató vállalkozás. Reményteli kivételt jelent a tanulmányban bemutatott szekszárdi társadalmi vállalkozás jó gyakorlata. A Kék Madár Alapítvány példája rávilágít arra is, hogy a turisztikai szektorban nemcsak vendégként, hanem munkavállalóként is lehet és kell is számolni a fogyatékossággal élő személyekkel.
\end{abstract}

Kulcsszavak: akadálymentes turizmus, inkluzív turizmus, társadalmi vállalkozás, Kék Madár Alapítvány Ízlelö étterem, BeSweet csokoládémanufaktúra

\begin{abstract}
Barrier-free tourism gives people with physical and intellectual disabilities a chance to experience tourism, as do their healthy peers. The need of people with disabilities to participate in tourism is becoming more common these days. However, the offer of barrier-free tourism services available in Hungary significantly narrows their possibilities. In Hungary, there are only a few companies that specialize in or support barrier-free tourism. A hopeful exception is the good practice of a social enterprise in Szekszárd presented in the study. The example of the Kék Madár Alapítvány (Blue Bird Foundation) also highlights that people with disabilities can and should be considered not only as guests but also as employees in the tourism sector.

Keywords: barrier-free tourism, inclusive tourism, social enterprise, Kék Madár Alapítvány (Blue Bird Foundation), Ízlelö family-friendly restaurant, BeSweet chocolate manufactory
\end{abstract}




\section{Bevezetés}

A fogyatékossággal élő személyek esélyegyenlőségének elősegítésére a mindennapokon túl a turizmusban is igény jelentkezik. Annál is inkább, hogy a számukra kialakított speciális eszközök, berendezések az ép embereket is kedvezően érinthetik utazásaik során, nekik is megkönnyíthetik az élményekhez való hozzáférést.

A még szükösen rendelkezésre álló, elszórtan megjelenő akadálymentes turisztikai programok, szolgáltatások szekszárdi kínálatából kiemelkedik a Kék Madár Alapítvány jó gyakorlata. A társadalmi vállalkozás egészségükben károsodottakat, látás-, mozgás-, hallássérülteket, tanulásban akadályozottakat, intellektuálisan sérülteket, autistákat foglalkoztat többek között vendéglátó és turisztikai munkaterületeken. Létesítményeik alkalmasak a fizikai, illetve az értelmi képességeikben akadályozott személyek fogadására. Integrált, sokszor egyedi programjaik pedig az élmények nyújtásán túl hozzájárul az előítéletmentességhez, az elfogadáshoz.

\section{Módszerek}

Külső adatforrásként elsősorban korábbi kutatásokat, tudományos publikációk elemzéseit vettem figyelembe a téma feldolgozásánál. A szekszárdi akadálymentes turizmus lehetőségeinek felmérését a kevés irodalmi adat mellett a helyszínek bejárásakor saját megfigyeléseim, valamint a szolgáltatók honlapjain szereplö leírások segítették. A kérdéssel kapcsolatos szakirodalom áttekintésén túl a Kék Madár Alapítvány tevékenységének bemutatásához, értékeléséhez annak ügyvezetőjével, Mészáros Andreával és az alapítvány által müködtetett BeSweet manufaktúra üzemvezetőjével, Blaskovits Péterrel készítettem interjúkat. Az alapítvány tevékenységét turisztikai szempontból - különösen az akadálymentesített turisztikai szolgáltatások tekintetében - korábban nem térképezte fel senki. Így ezzel a módszerrel juthattam leginkább számomra értékes információkhoz. Közvetlen kapcsolatot kialakítva az érintettekkel, sikerült közelebb kerülnöm a szakemberek gondolkodásmódjának, szemléletének megértéséhez. Mindemellett - az Alapítvány müködését évek óta követve, szolgáltatásaikat igénybe véve - személyes tapasztalataim, az Alapítványról szóló újságcikkek, internetes források is hozzájárultak a tanulmány megírásához.

\section{Elméleti háttér}

\subsection{Akadálymentesség a turizmusban}

Hazánkban az igazoltan fogyatékossággal élök a teljes lakosság csaknem 4,5\%-át teszik ki (http://www.ksh.hu/nepszamlalas/tablak_fogyatekossag). Bizonyos adatok szerint azonban akár másfél millió embert is korlátozhatnak megszokott aktivitásukban egészségügyi nehézségeik. Különösen a szépkorúak között vannak nagy arányban azok, akik egészségi állapotuk miatt valamilyen területen korlátozottnak, segítségre szorulónak minősítették magukat. Bárki kerülhet olyan élethelyzetbe, hogy szüksége lehet akadálymentesítésre. Ezáltal az akadálymentes turizmus célcsoportjai nemcsak a fogyatékossággal élők, hanem mindenki, aki átmenetileg vagy tartósan valamely képességében akadályozott (pl. várandós, babakocsit toló, bottal járó, gipszelt karú stb.) (ZSARNÓCZKY 2018). A jóléti országok korszerkezetének változása az egyre idősebb életkorban utazókat jósolja. A szenior korosztály számottevő részét érinti ideiglenesen vagy huzamosan valamilyen egészségkárosodás, amely a turizmusban való részvételükre, mozgásukra, észlelésükre is következménnyel van. 
Az akadálymentesített környezet kényelmesen és megbízhatóan használható a számukra is. Gyakran a fogyatékossággal élökéhez hasonlóak az igényeik a kisgyermekes családoknak is (DARCY, S. DICKSON, T. J. 2009).

Az Egyesült Nemzetek 2006-ban elfogadott Fogyatékossággal élő személyek jogairól szóló egyezmény kötelezi az együttmüködő országokat - köztük Magyarországot is -, hogy biztosítsák a fogyatékossággal élő személyek hozzáférését a sport, az üdülési és turisztikai helyszínekhez és szolgáltatásokhoz (https://net.jogtar.hu/jogszabaly?docid=a0700092.tv., SCHMIDTCHEN et al. 2020). A téma fontosságát mutatja, hogy a Magyar Turisztikai Ügynökség a Turisztikai Innovációs Marketing Együttműködési Alapprogram (TIMEA) projekt keretében módszertani segítséget nyújt a vállalkozóknak az akadálymentes fejlesztésekhez (https://turizmus.com/szabalyozasorszagmarketing/turizmus-akademiaval-segiti-a-vallalkozasokat-az-mtu-1166466), és a Magyar Szállodák és Éttermek Szövetsége is készített komplex akadálymentesítési ajánlást tagjaiknak. A fizikai hozzáférés, a desztinációkba való eljutás, a szolgáltatások igénybevétele mellett azonban a valós cél, hogy a fogyatékossággal élő turisták minőségi életet tudjanak élni a célhelyen és élvezni is tudják a felkeresett úti cél nyújtotta kínálatot. A fogyatékossággal élők számára ugyanúgy, mint más társadalmi csoportok részére fontossá vált az életminőséghez szorosan kapcsolódó elégedettség, boldogság, biztonsági faktorok és az érzelmek szerepe (DIENER et al., 1995). A fogyatékossággal élő személyek, az akadálymentesítést igénylő turisták csak akkor tudják problémamentesen élvezni az utazást, ha a turisztikai termék akadálymentessége teljeskörüen megvalósul (GÁLNÉ KUCSÁK 2008). Az esélyegyenlőség jegyében a mozgásszervi és látásszervi fogyatékosokon kívül akadálymentesíteni szükséges a környezetet - az egyre nagyobb számú - a hallássérültek, az értelmi képességükben korlátozottak, beszédfogyatékosságokkal élők, valamint az autisták számára is, az ő kisebb létszámuk ellenére (FARKAS - PETYKÓ 2020). A jó akadálymentesítés nem kényszerű megoldás. A segítséggel élők is szívesebben használnak - amennyiben lehet - az épekkel közös infrastruktúrát, mint olyan eszközöket, berendezéseket, amik csak őket szolgálják, és így rájuk irányítják a nem kívánt figyelmet. A fizikai akadályok elhárítása mellett mentális akadálymentesítés, társadalmi szemléletformálás, érzékenyítés is szükséges (BUHALIS et al. 2012, KOVÁCS - KOZÁK 2016). A hozzáférhető, hiteles naprakész információk minden utazó számára kulcsfontosságúak. Fokozottan érvényes ez a fogyatékossággal élő látogatók számára, hogy megalapozott döntést hozhassanak mind az úti cél kiválasztásával, mind pedig az ott igénybe veendő szolgáltatásokkal kapcsolatosan (ZAJADACZ LUBARSKA 2020).

A fogyatékossággal élők utazásaira alapuló piac egy jelenleg még kiaknázatlan turisztikai terület hazánkban. Igényeik, elvárásaik lényegében nem térnek el ép társaikétól. Számukra is turisztikai motivációt jelent a pihenés, a kikapcsolódás és a szabadidő minőségi eltöltése. Így bekapcsolásuk a turizmusba körültekintő munka mellett nem ütközne különösebb akadályokba (GONDA - RAFFAY 2020). Hangsúlyozni kell azonban, hogy a fizikai és az online tér akadálymentesítésnek nem szabad megállnia a mozgáskorlátozott személyek igényeinek kielégítésénél. Ennek ugyanis már vannak jó példái a hazai turizmusban. Azonban az egyéb fogyatékosságokkal élök elvárásait is figyelembe kell venni a beruházásoknál, a turisztikai termékek fejlesztésénél. Számukra is hozzáférhetővé kell tenni azokat. Egyértelmüen bizonyított, hogy az akadálymentes turizmus jövedelmező szegmense lehet a turizmus szakmának. A turisztikai fejlesztési koncepciókban akár kiemelten is kezelhetik kidolgozva egy új felelős és fenntartható turisztikai modellt (GONDA et al. 2014, HLIVA, 2018). 
Mindehhez szorosan hozzátartozik a turizmusban és az egyéb szolgáltató szektorban dolgozó humán erőforrás képzése is, hogy a fogyatékossággal élő vendégek fogadása és kiszolgálása minden területen minél zökkenőmentesebb, emberségesebb és elöítélet nélküli legyen (ANGLER 2020).

\subsection{Mindenki számára hozzáférhető turisztikai szolgáltatások Szekszárdon}

Szekszárd neve már nem csak a szőlőtermesztéssel, bortermeléssel foglalkozók számára fonódik össze a bor, a jó minőségü vörösbor képzetével. A szekszárdi borok itthon, és külföldön egyaránt népszerüségnek örvendenek a fogyasztók körében. Az elmúlt húsz évben a városban megvalósult borturisztikai fejlesztéseknek, a városvezetés által felismert - a szekszárdi borban és helyi gasztronómiában rejlö - vonzeröre alapozódó beruházásoknak, rendezvényeknek köszönhetően a turisták is egyre növekvő számban fedezik fel a borvidék névadó településének ezen arcát (ANGLER 2016). Szekszárd ugyanakkor számos építészeti (Belvárosi Plébániatemplom, Régi Vármegyeháza stb.), irodalmi és müvészettörténeti emlékkel (Babits Mihályhoz, Garay Jánoshoz, Mészöly Miklóshoz kötődő emlékek, Mattioni Eszter állandó kiállítása stb.) büszkélkedhet, amelyeket szintén érdemes a turistáknak felkeresniük. A város mediterrán hangulata, népszerü sportversenyei (Borvidék félmaraton, Gemenc Kupa stb.), fesztiváljai (Szekszárdi Szüreti Napok, Háry Mesefesztivál, Szekszárdi Hal- és Vadünnep stb.), különleges múzeumai (Wosinszky Múzeum, Bogár tanya, Mézeskalács Múzeum stb.), gazdag kulturális kínálata, a Gemenci-erdő közelsége is csalogatják a látogatókat. Az ideérkezőket szálláshelyek, vendéglátóegységek széles választéka várja.

A fogyatékossággal élő személyek hozzáférése ezen szolgáltatásokhoz azonban nem zökkenőmentes, hiszen a város akadálymentesítése még mindig hagy kívánnivalót maga után. 2019-ben a város szolgált helyszínéül az Értelmi fogyatékkal élők összmúvészeti fesztiváljának (https://csalad.hu/cikk/osszmuveszeti-fesztival-fogyatekkal-elokkel).

Már található néhány akadálymentes szálláshely a városban (pl. Merops Hotel, Takler Kúria, Szép Kert Panzió stb.), ezeknek száma azonban elenyésző. További probléma, hogy a szálláshelyeken - a Bodri Birtok kivételével, ahol több szoba is alkalmas mozgásukban korlátozott vendégek fogadására - csupán egy-egy akadálymentes szobát alakítottak ki. Ezek mindegyike kizárólag a mozgáskorlátozottak speciális igényeit veszi figyelembe, egyéb fogyatékossággal élőkre nem gondoltak. Ugyanígy szinte kizárólag a mozgáskorlátozottakra fókuszálnak azok a szekszárdi éttermek, rendezvényhelyszínek is, amelyek feltüntek az akadálymentes turizmus szolgáltatói között.

A látnivalók közül különösen a múemléki védelem alatt álló épületek megközelítése megoldatlan, bár örvendetes, hogy mind az evangélikus templom, mind az Újvárosi katolikus templom és a Belvárosi plébániatemplom is biztonságos, kényelmes rámpán elérhető. Tolna megye legnagyobb múzeuma, a Wosinszky Mór Megyei Múzeum kompromisszumos megoldásként csupán néhány termét tudja a mozgásukban korlátozottak számára bemutatni. Így a földszinti termek, valamint egy hernyótalpas szék segítségével a pincében található Látványtár is látogatható (MÁTÉ 2020, http://wmmm.hu/diakfoglalkoztato-es-oktato-ter/). Egy hangos felolvasó modul a mozgás- és hallássérült látogatók számára egyaránt hozzáférhetővé teszi az információkat. A Wosinszky Múzeumon kívül a Babits Emlékház, Az Irodalom Háza és a Vármegyeháza kiállításai is biztosítanak gömbpanoráma felvételek révén virtuális túrát a mozgásukban korlátozott látogatók számára a nehezen elérhető terek tartalmáról. Egyes mütárgyakat Braille-írással is feliratoztak, segítve ezzel a vakok és gyengénlátók múzeumi élményszerzését. 
A városközpontban 2014-ben létrehozott Garay Élménypince interaktív kiállítása a Szekszárdi borvidékről szolgál érdekes és értékes információkkal, továbbá a kulturált borfogyasztást, valamint a magyar borkultúrát népszerüsíti (https://www.garaypince.hu/). A borélmény-körút egésze teljeskörüen hozzáférhető a látás-, a hallássérülteknek, valamint a mozgásukban korlátozottak számára. A létesítményt - akár kerekesszékkel is - végigjárhatják a látogatók (SLEZÁK-BARTOS et al. 2020.).

A városban évről évre nő azoknak a tereknek, gyalogos zónáknak a száma, ahol süllyesztett szegélyek segítik a közlekedést. Az új, illetve a felújítandó középületek tervezésekor, kivitelezésekor - a jogszabályoknak megfelelően -, nemcsak a mozgásukban korlátozottak, de a látás- és halláskárosultak, autisták igényeire is figyelnek. Így tájékoztató (braille írásos), illetve hangos táblák, liftek, indukciós hurok, taktilis vezetősáv, vibrálásmentes lámpák és akadálymentes liftek segítik a fogyatékossággal élö helyieket és a városba érkező turistákat. Jó példa erre a Babits Mihály Kulturális Központ, melynek megújult épülete mozgáskorlátozottak számára teljeskörüen akadálymentes, mozgáskorlátozott parkoló, rámpa, lift, akadálymentes mosdó áll rendelkezésükre. Emellett taktilis vezetősáv, indukciós erősítés segíti a látás-, illetve hallássérülteket. A most készülő Sió vízi turisztikai fejlesztésnél a megálló-épületek teljes körü, komplex akadálymentesítése szerepel a terveken (http://www.tolnamegye.hu/fooldal/palyazatok/a-sio-vizi-turisztikai-fejlesztes). A szekszárdi autóbusz-állomás utasforgalmi területei szintén elérhetőek akadálymentesen, hangos utastájékoztatás, összevont és kocsiállási kijelző müködik. (https://www.efiportal.hu/fszk_sajnevtan/del-dunantulikozlekedesi-kozpont-zrt-akadalymentes-autobusz-allomasai/).

\section{A Kék Madár Alapítvány jó gyakorlatának bemutatása}

A Szekszárdi székhelyü Kék Madár Alapítvány külföldi példa alapján jött létre. Fő célként a valamilyen szempontból segítségre szoruló személyek, időszakosan, vagy tartósan nehéz helyzetbe kerültek, fogyatékossággal élők, alacsony iskolai végzettségüek támogatását fogalmazták meg. Napjainkra számtalan hazai és nemzetközi elismerést zsebeltek be munkájuk jutalmaként.

\subsection{Az Alapítványról}

A Kék Madár Alapítvány egy 1997-ben alapított modell értékü társadalmi vállalkozás, mely 2002 óta végez munkaerőpiaci szolgáltatásokat. Küldetésük többek között, hogy a fogyatékkal élö, munkaerőpiacról kiszorult emberek életminőségét javítsák, életcélt adjanak nekik. Ennek egy eszköze, hogy - átlátható és méltányos, az egyéni teljesítményhez igazodó bérezést biztosító - munkához juttassák őket.

Ennek érdekében 2007-ben az Alapítvány létrehozta Szekszárdon, a történelmi városmag közvetlen közelében az Ízlelő családbarát éttermet (1. kép), ahol - a vezetők kivételével - mindenki fogyatékossággal élő dolgozó (pl. értelmileg akadályozott, mozgássérült, különféle betegségek miatt egészségkárosodott, autizmussal élő, aspergeres emberek stb.). 


\section{1. kép Ízlelő családbarát Étterem Szekszárdon}

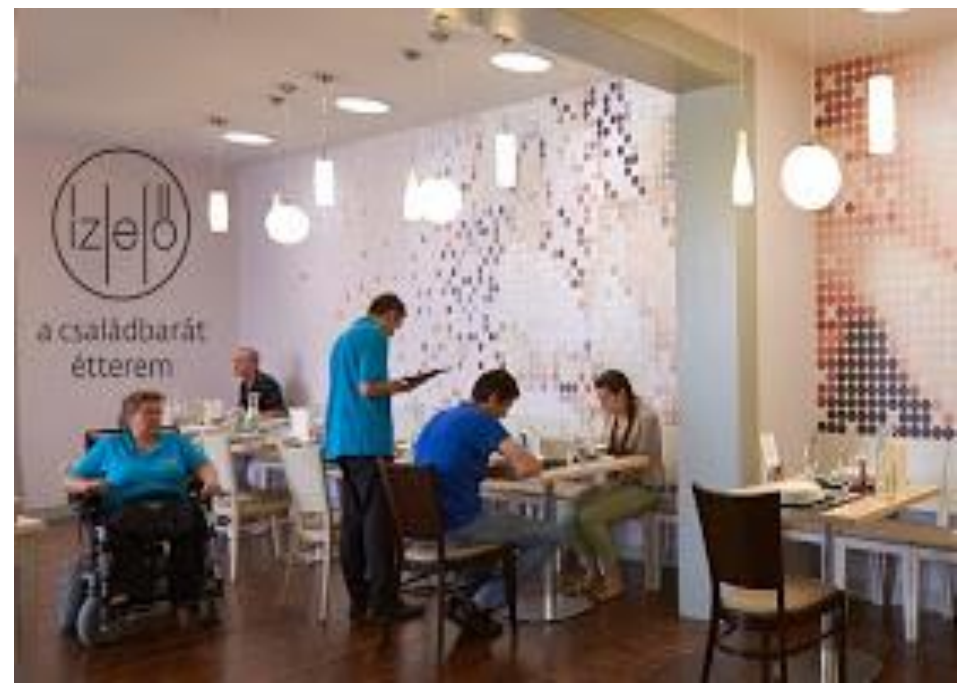

Forrás: http://kek-madar.hu/izlelo-csaladbarat-etterem/(letöltve: 2020. 10.05.)

2016-ban az éttermi ételkészítés számára fogtak bele minőségi helyi alapanyagokból, kíméletes eljárással magas gyümölcstartalmú lekvárok, szörpök készítésébe. A Kékmadár Csokigyár és Élelmiszermanufaktúra megteremtette a Szekszárdi Csoki brandet (2. kép).

\section{2. kép Szekszárdi csoki}

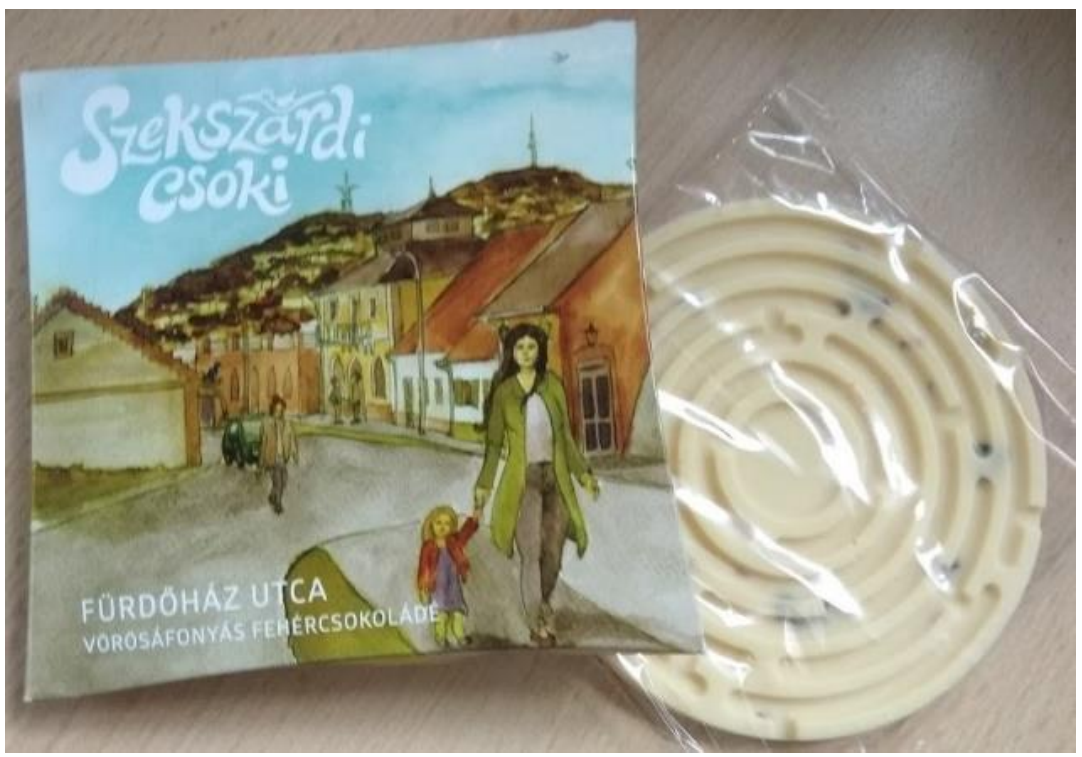

Forrás: Saját felvétel, 2020

A szekszárdi kedvező tapasztalatok és a speciális szükségletü személyek foglalkoztatásának nyilvánvaló igénye hívta létre 2019-ben Budapesten a Hegyvidéki Ízlelö Éttermet.

2020 nyarán pedig megnyitották Szekszárd külvárosában a BeSweet látogatható csokoládémanufaktúrát (http://kek-madar.hu/2018/03/08/kekmadar-csokigyar-eselelmiszermanufaktura-latogatokozpont/). 
Ezen vállalkozások révén az Alapítvány maga is a megváltozott munkaképességü dolgozók foglalkoztatójává vált. Így egyrészt saját bevételt generálnak az Alapítvány számára, forrást biztosítva ezzel a munkaerőpiaci szolgáltatások folyamatos működtetéséhez. Másrészt jó példával szolgálnak a térség munkáltatói számára, hogy a fogyatékossággal élő emberek is értékteremtővé válhatnak egy vállalkozásban. Mindegyik vállalkozásuk tevékenysége jellegéből adódik, hogy különböző képességü munkavállalókat igényel.

\subsection{Fogyatékossággal élő munkavállalók}

Az éttermek és a csokoládéüzem müködésében megjelenő feladatok széles palettája egyaránt remek lehetőséget nyújt értelmi fogyatékos, mozgássérült, látássérült, vagy más munkaképességében akadályozott, vagy kognitív zavarral élő, autista stb. munkavállalók számára (3. kép). A munkaszervezésben igyekeznek a bonyolultabb munkafolyamatokat a vezetők olyan apró mozzanatokra bontani, amelyeket el tudnak látni beosztottjaik. Az Alapítvány szakmai képzéseket szervez a dolgozóknak, hogy a magabiztos munkavégzéshez szükséges megfelelő képességeket, képzettséget megszerezzék. A testhezálló feladatok, munkakörülmények megteremtése révén a fogyatékossággal élők, a megváltozott munkaképességü emberek is a társadalom hasznos tagjaivá válhatnak, megmutathatják sokszínüségüket, képességeiket és akaraterejüket (RAFFAY - GONDA 2020).

\section{3. kép Hegyvidéki Ízlelő}

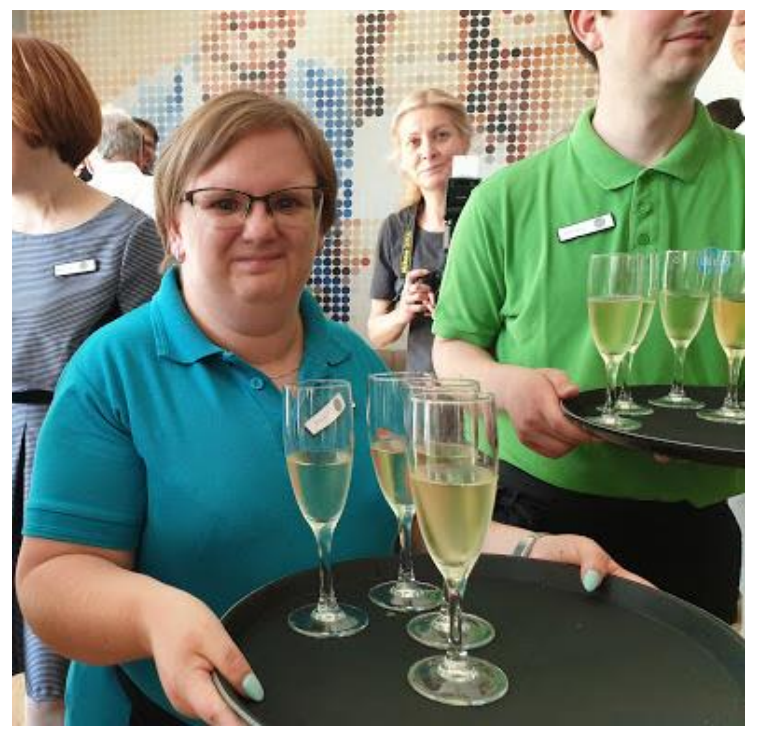

Forrás: http://turizmusonline.hu/belfold/cikk/sokszinuseg_elfogadas_es_szivbol_jovo_vendeglatas (letöltve: 2020. 10. 05.)

A munkavégzés tereinek tervezésénél - az épület kialakításánál, az eszközök beszerzésénél - a hangsúly az akadálymentesítésen, a hozzáférhetöségen és a könnyített eszközhasználaton volt. A cél, hogy a munkaeszközök, a terek minden munkavállaló számára a lehető legnagyobb mértékben önállóan hozzáférhetőek és kényelmesen, biztonságosan, ugyanakkor hatékonyan használhatóak legyenek adaptálás, vagy speciális tervezés szükségessége nélkül. A rehabilitációs elveken nyugvó ergonómiai tervezés során megvalósult az ember és a technikai környezet közötti harmónia. 
Az ergonómiailag jól megtervezett, kivitelezett rehabilitációs eszközök (akadálymentes bejutás, nagy nyílásméretű ajtók, akadálymentes útvonal, rámpák, kapaszkodók, korlátok, zuhanyszékek, akadálymentes csaptelep, kilincs stb.) könnyen használható környezetet biztosítanak a munkavállalóknak (4. kép). Természetesen akadálymentes mosdó, vécé nemcsak a dolgozók számára elérhető, hanem a fogyasztótérben a látogatók számára is kialakították azt.

\section{4. kép Akadálymentes elemek a személyzeti szociális helyiségekben}

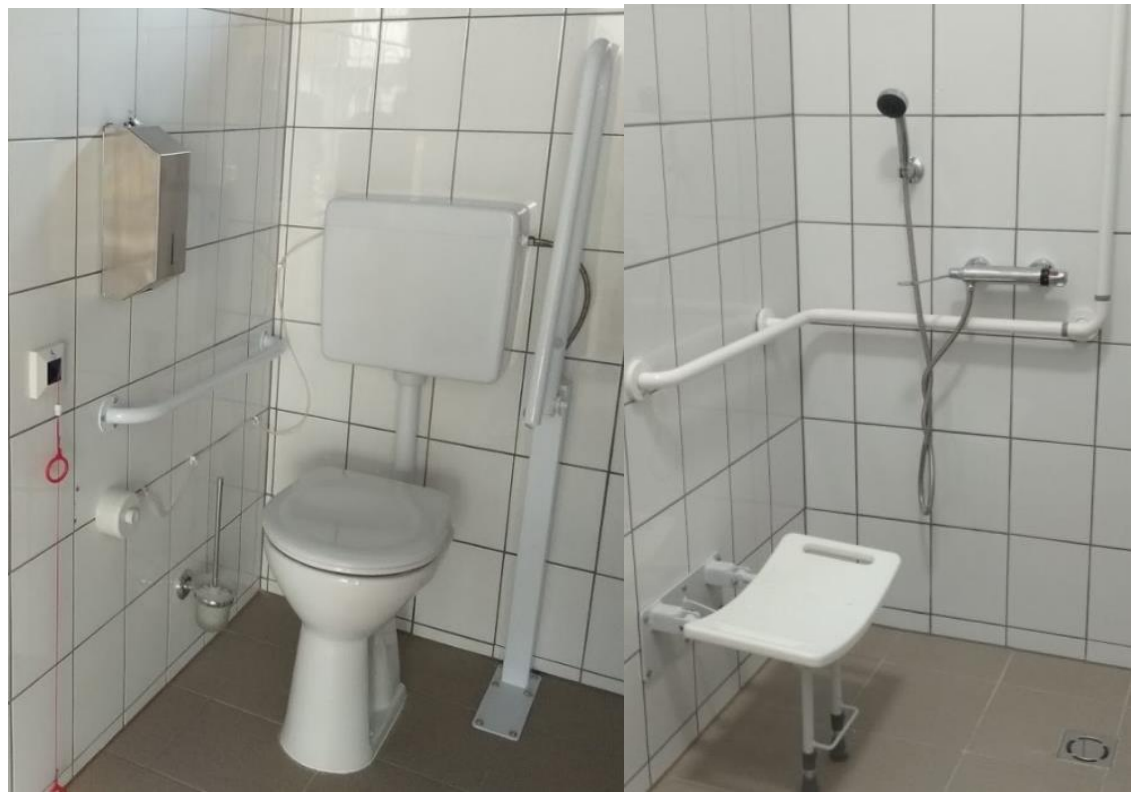

Forrás: Saját fénykép (2020)

\subsection{Az akadálymentes turizmusba való bekapcsolódás}

Az Alapítvány éttermei elsősorban a helyi lakosság napi ellátására és alkalmi étkeztetésére törekednek. Menüs étkeztetést nyújtanak helyben fogyasztással, előrendelési és elviteli lehetőséggel, ételkiszállítással. Vendégeik között sok a kisgyermekes család, hiszen a kialakított környezet családbarát (játszósarok, etetőszék, gyermekterítékek, pelenkázó stb.). Étkeznek náluk egészségtudatos életmódot fontosnak tartók, különböző ételallergiával, egészségügyi problémával küzdők is. Számukra egyéni szükségleteiknek megfelelő ételeket készítenek. A budapesti éttermet több fogyatékossággal élő vendég keresi fel, még segítő (vakvezető) kutyával is érkeznek. Szekszárdon idősek, nehezebben mozgók, és kisgyermekesek a leggyakoribb vendégek.

Az Access4you speciális igényü emberek számára nyújt információt az akadálymentes hozzáférésről. Minősítési és tanúsítási rendszere alapján mind a budapesti Hegyvidéki Ízlelő mind a szekszárdi Ízlelő éttermek egyaránt arany fokozatú minősítést kaptak. Eszerint minden speciális igényü ember számára megközelíthetőek az éttermek és szolgáltatásaik elérhetőek, valamint adott a területükön való szabad mozgás lehetősége is (http://news.access4you.io/2020/08/27/akadalymentesen-kivul-belul-aranyfokozatu-access4you-minositest-kapott-az-izlelo-mindket-etterme/). 
Bár nem merült fel elsődleges célként a turisták ellátása, de idővel az Alapítvány vendéglátó szolgáltatásai turisztikai kínálati elemmé is váltak. Többek között a városban való frekventált elhelyezkedése is hozzájárult ahhoz, hogy számos kirándulócsoport étkezett már az Ízlelőben. Szerveznek gasztronómiai esteket, borvacsorákat neves borászokkal, különböző rendezvényeket, vagy éppen külső helyszínen nyújtanak cateringet (5. kép).

\section{5. kép Borvacsora az Ízlelő Étteremben}

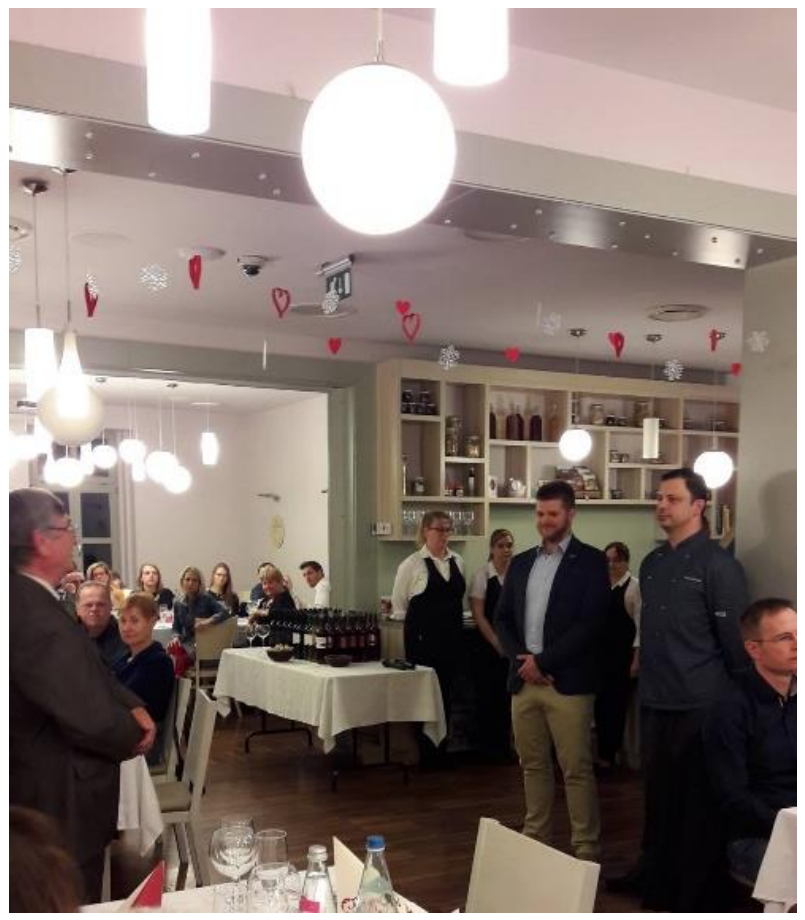

Forrás: https://www.facebook.com/izleloetterem/photos/a.124706047594266/1750741154990739 (letöltve: 2020. 10. 05.)

A BeSweet Csokoládémanufaktúra létrehozásában azonban konkrét célként fogalmazódott meg a vállalkozás turizmusba történő bekapcsolása. Már a korábbi csokoládéüzem müködésekor számos megkeresést kapott az Alapítvány - elsősorban oktatási intézmények részéröl -, hogy szívesen megtekintenék a csokoládékészítés folyamatát. Erre azonban a korábbi műhely nem volt alkalmas. Az új helyszín a várost átszelő főközlekedési úttól letérve, de annak közvetlen közelében található. A jelenlegi csokoládémanufaktúrában egy üvegfal segítségével - a higiénés elöírások betartásával betekinthetnek az érdeklődők a csokoládékészítés rejtelmeibe (6.kép). 


\section{6. kép Bepillantás a csokoládémanufaktúra mühelyébe az üvegfalon keresztül}

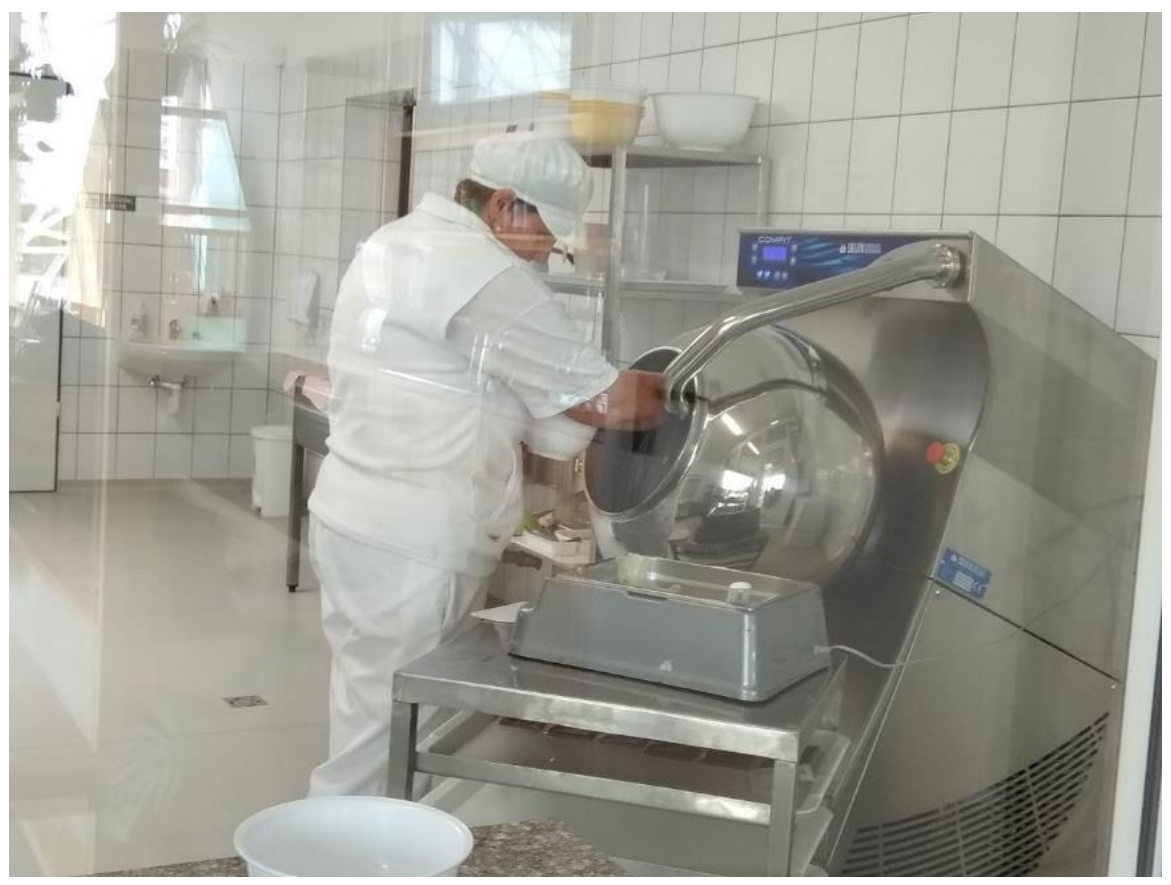

Forrás: Saját fotó, 2020.

$\mathrm{Az}$ akadálymentes turisztikai látogatóközpontban termékbemutató és értékesítőpont müködik. A közösségi tér büféjében saját készítésü frissítők, kávé, snackek, szendvicsek kaphatók. A beltéren játszósarok, az udvaron játszótér várja a kicsiket (http://kek-madar.hu/2018/03/08/kekmadarcsokigyar-es-elelmiszermanufaktura-latogatokozpont/, https://besweet.hu/rolunk/ (7., 8. kép).

\section{7. kép Játszósarok a BeSweet Csokoládémanufaktúrában}

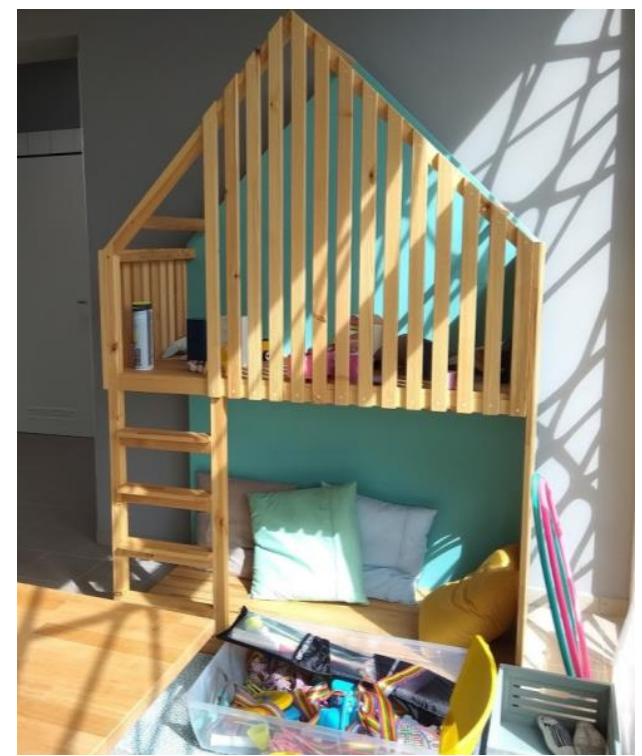

Forrás: Saját fotó, 2020. 


\section{8. kép Játszótér a BeSweet Csokoládémanufaktúra udvarán}

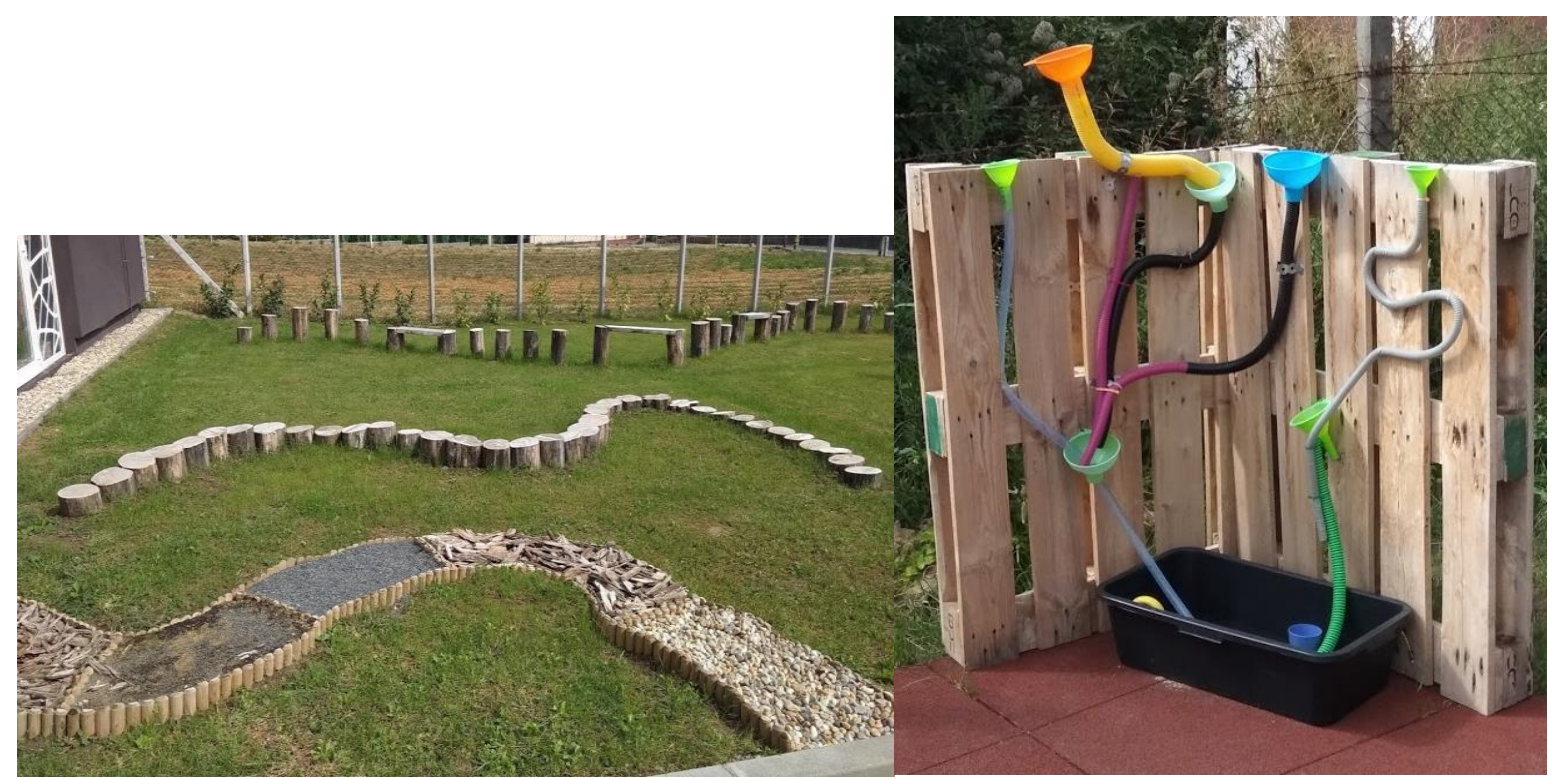

Forrás: Saját fotó, 2020.

Az Alapítvány ingatlanjainál cél a teljes akadálymentesítés. Az új létesítményeknél a környező járda és a földszinti padló között nincs szintkülönbség, ezért a bejutáshoz sem rámpa, sem elölépcső nem szükséges (9. kép). Akadálymentes útvonalon elérhető, akadálymentes parkolók állnak rendelkezésre, hiszen az akadálymentességnek mindig a meglátogatandó épület parkolójától kell kezdődnie.

\section{9. kép Akadálymentesen megközelíthető bejáratok}

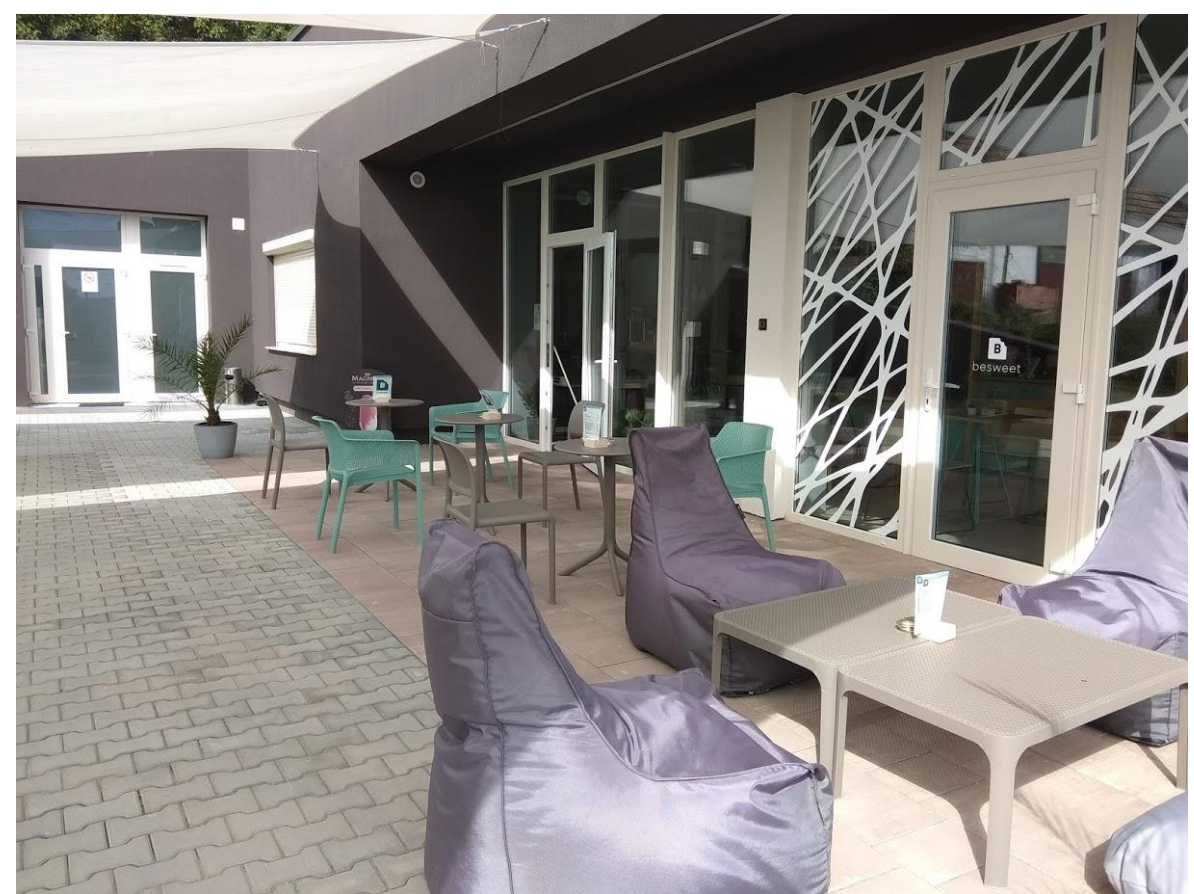

Forrás: Saját fotó, 2020. 
A kommunikációs akadálymentesítés elemei a Braille-írással ellátott információs, irányjelző és helységjelző táblák, melyek segítik az itt dolgozók és a vendégek tájékozódását, egyenlő esélyt biztosítva a mindenki számára hozzáférhető információhoz (10. kép).

10. kép Braille-írással ellátott táblák a személyzeti részen, illetve a vendégtérben

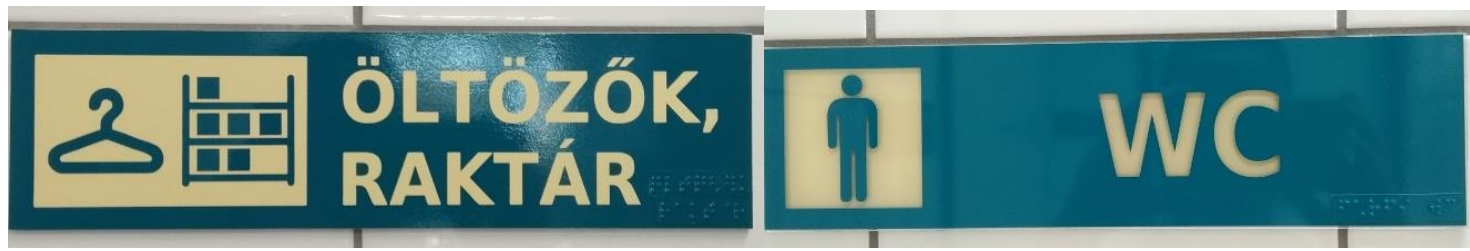

Forrás: Saját fotó, 2020.

A hallókészüléket használók számára erősíti fel a hangokat, segítve a kommunikációjukat az indukciós hurok (11. kép).

\section{1. kép Elérhető mobil indukcióshurok-erősítő a BeSweet közösségi terében}

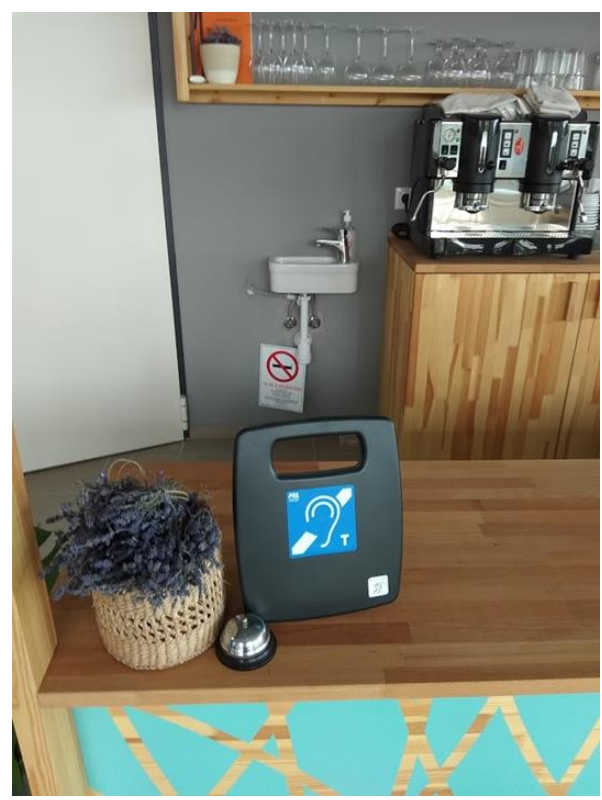

Forrás: Saját fotó, 2020.

Ahogy a korábbiakból már kiderült, mind az Alapítvány éttermei, mind a csokoládémanufaktúra üzemi területei és vendégterei is akadálymentesítettek, így alkalmasak szolgáltatásaik az akadálymentes turizmust igénylők számára. Fel is készült fogadásukra mindegyik szolgáltatóhely. Az Alapítvány vezetése azonban inkább integráció-párti, mint kizárólag a valamilyen akadályozottsággal élők számára kínálják szolgáltatásaikat. A turizmus terén az inkluzív turizmust preferálják, ahol a társadalom ép csoportjai megkülönböztetés és kirekesztés nélkül fogadják be a fogyatékossággal élö társaikat. Hiszen az akadálymentesítést igénylő turista nem eltérő szolgáltatási kínálatot igényel, hanem ugyanazokat az élményeket keresi utazása során, mint az épek. Éppen ezért az Alapítvány olyan programokat szervez, amelyek lehetőség szerint integráltak. Azonban a programok elemeit, az interpretálást a résztvevők felmerülő speciális igényeihez igazítják, hogy mindannyian teljes mértékben élvezni tudják a náluk tartózkodás örömeit. 
Erre törekedve állítják össze a BeSweet turisztikai kínálatát is, melyek között munkavállalóik tevékenységének bemutatása, az etikus kereskedelem ismertetése, a csokoládékészítés fortélyai, borés csokoládékóstoló, gasztronómiai workshopok, érzékenyítő tréningek is szerepelnek. Mindezeket animált foglalkozások keretében, élménypedagógiai elemekkel színesítve valósítják meg. A fennálló elöítéletek, gátak lebontásában ez a szemlélet segíthet.

A kézzelfogható és látható fejlesztések, a környezet fizikai akadálymentesítése mellett a turizmusban, a vendéglátásban dolgozók mentális és viselkedésbeli akadálymentesítése is szükséges. A Kék Madár Alapítvány esetében a vendégek, turisták fogadását is többnyire megváltozott munkaképességü, sérült, vagy valamilyen fogyatékossággal élő munkavállaló végzi. Elengedhetetlen az alkalmazottak képzése a hozzájuk érkezőkkel való bánásmód, kommunikáció terén. Érzékenyítésük természetesen más módszereket, eszközöket kíván, mint ép társaik esetében. Ehhez az Alapítvány szakemberek támogatását veszi igénybe, hiszen minden tekintetben minőségi szolgáltatások nyújtása a cél. Így érhető el, hogy ép látogatóik túllépjenek az elöítéleteiken, és ne sajnálatból, ne együttérzésből vegyék igénybe szolgáltatásaikat, hanem azért, mert azok versenyképesek a piacon. A valamilyen akadályozottsággal küzdők számára pedig adottak a feltételek, hogy turisztikai élményekhez juthassanak. Az ideérkezők számára bebizonyosodik - függetlenül attól, hogy egészségesek, vagy fogyatékossággal élők -, hogy megfelelö körülmények biztosítása mellett egy speciális igényü ember is képes értékteremtő munkavégzésre.

\section{Összegzés}

A fogyatékossággal élő személyek igénye a turizmusba való bekapcsolódásra egyre gyakoribb. A prognózisok alapján feltételezhető, hogy az akadálymentes turizmus piaca egy gyorsan növekvő piac, mely az ezzel foglalkozók számára akár kiemelkedő jövedelmet is biztosíthat.

Szekszárd turisztikai kínálatában ugyan már akadnak olyan szolgáltatások, illetve turisztikai termékek, melyek a különböző fogyatékossággal élők számára is hozzáférhetőek, azonban ezek még tartalmukban, komplexitásukban, változatosságukban és számukban is fejlesztésre, bővítésre szorulnak.

A Kék Madár Alapítvány éttermei és csokoládémanufaktúrája alkalmasak az akadálymentes turizmusba való aktív részvételre. Az egyes programelemek kreatívak, egyediek, különlegesek, piacképesek. A létesítmények és a vendégfogadásban közremüködők rendelkeznek az akadálymentes turizmushoz szükséges feltételekkel, készségekkel. Az Alapítvány esélyt kínál a fogyatékossággal élők turizmusba történő bekapcsolódására - akár mint munkavállalók, akár mint turisták kívánnak részt venni abban. Tevékenysége során példaértéküen valósul meg a fenntarthatóság és társadalmi felelősségvállalás egyaránt. Érdemes a lehető legszélesebb körben ismertté tenni tevékenységüket, bízva abban, hogy jó példájuk követőkre talál. 


\section{Irodalomjegyzék}

ANGLER, K. (2020): Opportunities for people with disabilities in tourism In: Gonda, Tibor; Schmidtchen, Roger (szerk.) Opportunities and challenges of barrier-free tourism in Hungary. Results and recommendations of a scientific workshop during the conference "European Peer-Counselor Training in Accessible Tourism - Peer-AcT" on September 4, 2020 in Orfü (Hungary) Bonn, Németország: Bundesinstitut für Berufsbildung (2020) 157 p. pp. 100-109., 10 p.

ANGLER, K. (2016): „Egyedül nem megy!” Formális és informális együttmüködések sikeres gyakorlatai Szekszárd borturizmusáért. In: Ivancsóné, Horváth Zsuzsa; Darabos, Ferenc (szerk.) „,Turizmus és innováció” viii. Nemzetközi turizmus konferencia 2016: tanulmányok Széchenyi István Egyetem, Györ 394 p. pp. 51-63., 13 p.

BUHALIS, D. - DARCY, S. - AMBROSE, I. (2012): Best Practice in Accessible Tourism - Inclusion, Disability, Ageing Population and Tourism. Channel View Publications, Bristol. pp. 39-59.

DARCY, S. - DICKSON, T. J. (2009): A whole-of-life approach to tourism: The case for accessible tourism experiences. Journal of Hospitality and Tourism Management 16: pp. 32-44.

DIENER, E. - DIENER, M. (1995): Cross-cultural correlates of life satisfactions and self esteem. Journal of personality and Social Psychology 68. pp. 653-663. https://link.springer.com/chapter/10.1007/978-90-481-2352-0_4 (letöltve: 2020. 08. 18.)

FARKAS, J. - PETYKÓ, CS. (2020): A fogyatékosság, az akadálymentesség és a mobilitás, mint egzisztenciális alaptulajdonság. Turisztikai és Vidékfejlesztési Tanulmányok 5: 4 pp. 43-55., 13 p. DOI: 10.15170/TVT.2020.05.04.03

GÁLNÉ KUCSÁK, K. (2008): A sötétség vándorai: A látássérültek turizmusának helyzete és esélyei Magyarországon. Turizmus Bulletin 12(2): pp. 53-59. https://mtu.gov.hu/documents/prod/Bulletin2008_2.pdf (letöltve: 2020. 08. 18.)

GONDA, T. - HUSZTI, ZS. - SLEZÁK-BARTOS, ZS - ROUSSET, C. A. - RAFFAY, Z. (2014): A vállalati társadalmi felelősségvállalás tartalmi változása: Az olaszországi jó gyakorlat bemutatása. Tudásmenedzsment 15: 2 pp. 90-98., 9 p.

GONDA, T. - RAFFAY, Z. (2020): Egyedül nem megy - fogyatékkal élők utazási szokásainak vizsgálata egy nemzetközi felmérés eredményeinek tükrében. In: Csapó, János; Csóka, László (szerk.) Kreativitás, változás, reziliencia. III. Nemzetközi Turizmusmarketing Konferencia: Tanulmánykötet Pécs, Magyarország: Pécsi Tudományegyetem Közgazdaságtudományi Kar, pp. 154-165., 12 p. https://doi.org/10.15170/MG.2020.15.04.01

https://ktk.pte.hu/sites/ktk.pte.hu/files/images/tudomany/rendezvenyek/turizmus-

marketing/Tanulm\%C3\%A1nyk\%C3\%B6tet-2020.pdf (letöltve: 2020. 08. 31.)

HLIVA, É. (2018): Egyedülálló kezdeményezés: akadálymentes turizmust kínálnak a sérülteknek. Heves megyei hírportál https://www.heol.hu/vezeto-hirek/akadalymentes-turizmus-1207828/ (letöltve 2020. 08. 18.)

KOVÁCS, T. - KOZÁK, A. (2016): Paraturizmus és konfliktusmenedzsment a szállodaiparban. Területfejlesztés és innováció 2: pp. 18-26.

MÁTÉ, A. (2020): Situation eines Komitatsmuseums und seine Möglichkeiten im barrierefreien Tourismus. In: Gonda, Tibor; Schmidtchen, Roger (szerk.) Opportunities and challenges of barrierfree tourism in Hungary. Results and recommendations of a scientific workshop during the conference "European Peer-Counselor Training in Accessible Tourism - Peer-AcT" on September 4, 2020 in Orfü (Hungary) Bonn, Németország: Bundesinstitut für Berufsbildung 157 p. pp. 53-72., 20 p. 
RAFFAY, Z. - GONDA, T. (2020): Az akadálymentes turizmus innovatív jó gyakorlata Modern geográfia 2020/IV. pp. 1-14.

http://www.moderngeografia.eu/wp-content/uploads/2020/10/2020_IV_01_raffay-gonda_v3.pdf (letöltve 2020. 10. 05.)

SLEZÁK-BARTOS, ZS. - MÁTÉ, A. - GULD, ZS. (2020): Accessible Wine Consumption and Purchase Opportunities for Hungarian Young Consumers. In: Gonda, T. - Schmidtchen, R. (Ed.) Opportunities and challenges of barrier-free tourism in Hungary. Results and recommendations of a scientific workshop during the conference "European Peer-Counselor Training in Accessible Tourism - Peer-AcT" on September 4, 2020 in Orfü (Hungary) Bonn, Németország: Bundesinstitut für Berufsbildung. 157 p. pp. 73-88.

SCHMIDTCHEN, R. - PATAKI, V. - TRZECINSKI, S. - PIEPENBURG, M. - PIEL, M. MIGNONE, N. - BAŠIĆ, A.L. - VUKOVIC, S. (2020): "European Peer Counselor Training in Accessible Tourism - Peer AcT" innovation for inclusion in adult training and inclusive tourism In: Gonda, Tibor; Schmidtchen, Roger (szerk.) Opportunities and challenges of barrier-free tourism in Hungary. Results and recommendations of a scientific workshop during the conference "European Peer-Counselor Training in Accessible Tourism - Peer-AcT" on September 4, 2020 in Orfui (Hungary) Bonn, Németország: Bundesinstitut für Berufsbildung (2020) 157 p. pp. 7-16., 10 p.

ZAJADACZ, A. - LUBARSKA, A. (2020): Sensory gardens as place for outdoor recreation adapted to the needs of people with visual impairments. Studia Periegetica nr2(30)2020 DOI:

10.5604/013001.0014.3170

ZSARNÓCZKY, M. (2018): The Future Challenge of Accessible Tourism in the European Union. Vadyba Journal of Management 2(33): pp. 39-43.

\section{Egyéb források:}

http://kek-madar.hu/2018/03/08/kekmadar-csokigyar-es-elelmiszermanufaktura-latogatokozpont/ (letöltve: 2020. 08. 19.)

https://besweet.hu/rolunk/ (letöltve: 2020. 08. 18.)

http://www.ksh.hu/nepszamlalas/tablak_fogyatekossag) (letöltve 2020. 08. 31.)

Indul a Turizmus Akadémia - jó gyakorlatok első kézből - turizmus.com 2019.10.10. (https://turizmus.com/szabalyozas-orszagmarketing/turizmus-akademiaval-segiti-a-vallalkozasokataz-mtu-1166466) (letöltve 2020. 08. 19.)

2007. évi XCII. törvény a Fogyatékossággal élő személyek jogairól szóló egyezmény és az ahhoz kapcsolódó Fakultatív Jegyzőkönyv kihirdetéséröl https://net.jogtar.hu/jogszabaly?docid=a0700092.tv.) (letöltve 2020. 08. 18.)

Akadálymentesen kívül-belül: arany fokozatú Access4you minősítést kapott az Ízlelő mindkét étterme 2020.08.27. http://news.access4you.io/2020/08/27/akadalymentesen-kivul-belul-arany-fokozatuaccess4you-minositest-kapott-az-izlelo-mindket-etterme/ (letöltve 2020. 08. 31.) https://csalad.hu/cikk/osszmuveszeti-fesztival-fogyatekkal-elokkel (letöltve 2020. 12. 08.) http://wmmm.hu/diakfoglalkoztato-es-oktato-ter/ (letöltve 2020. 12. 08.) http://www.tolnamegye.hu/fooldal/palyazatok/a-sio-vizi-turisztikai-fejlesztes (letöltve 2020. 12. 08.) https://www.garaypince.hu/ (letöltve 2020. 12. 08.) https://www.efiportal.hu/fszk_sajnevtan/del-dunantuli-kozlekedesi-kozpont-zrt-akadalymentesautobusz-allomasai/ (letöltve 2020. 12. 08.) 